\title{
The Self-Portrait as a Means of Self-Investigation, Self- Projection and Identification among the Primary School Population in Croatia
}

Dunja Pivac ${ }^{* 1}$ And Maja Zemunik

$\approx$ The self-portrait is a reflection of the personality in a visual, physical sense, as a concrete form, a summary of the external characteristics of the artist, but also in a psychological sense, when the self-portrait becomes a mediator of communication with the self, a medium of self-investigation. In this way, the self-portrait exists as a means of self-reflection, self-awareness and acceptance of the Self. It contains three primary values: subjective, objective and the archetype. Considering that the self-portrait is not exclusively a means of introspection reserved only for artistic practice, but also includes activities of the entire population, ranging from early childhood to old age, the projective and reflexive features of this motif began to be used for diagnostic and therapeutic purposes.

These findings, as well the need for a new role for art teachers arising from the cognitive, emotional and moral needs of children and youth involved in the regular education system in the Republic of Croatia, gave rise to the project The Self-Portrait as a Means of Self-Investigation, Self-Projection and Identification, which was realised in the regular primary educational process, in fifth-grade art classes. The expressive and projective dimensions of children's drawings, which can indicate the possibility of diagnostic and potentially therapeutic activity within the regular primary education system, were taken as a starting point. The project also sought to examine the impact of rational-cognitive principles of teaching on children's creativity and expression.

Keywords: children's art expression, diagnostics, education, selfportrait, self-projection

1 *Corresponding Author. Arts Academy, University of Split, Croatia; dunja.pivac@umas.hr.

2 Arts Academy, University of Split, Croatia. 


\section{Avtoportret kot sredstvo samoraziskovanja, samoprojekcije in identifikacije med osnovnošolsko populacijo na Hrvaškem}

Dunja Pivac in Maja Zemunik

$\approx$ Avtoportret je odsev osebnosti v vizualnem, fizičnem smislu kot konkretna oblika, povzetek zunanjih lastnosti umetnika, pa tudi v psihološkem smislu, ko avtoportret postane posrednik komunikacije s samim seboj, kot medij samoraziskovanja. Tako avtoportret obstaja kot sredstvo za samorefleksijo, samozavedanje in za sprejemanje jaza. Vsebuje tri osnovne vrste vrednot: subjektivno, objektivno in arhetip. Glede na to, da avtoportret ni izključno sredstvo introspekcije, rezervirano samo za umetniško prakso, ampak vključuje tudi dejavnosti celotne populacije, vse od zgodnjega otroštva do starosti, so se projektivne in refleksne značilnosti tega motiva začele uporabljati za diagnostiko in terapevtske namene. Te ugotovitve pa tudi potreba po novi vlogi likovnih pedagogov, ki izhaja iz kognitivnih, čustvenih in iz moralnih potreb otrok in mladine, vključenih v redni izobraževalni sistem na Hrvaškem, so sprožile projekt Avtoportret kot sredstva samoraziskave, samoprojekcije in identifikacije, ki je bil uresničen $\mathrm{v}$ rednem osnovnošolskem procesu pri pouku likovne vzgoje v petem razredu. Kot izhodišče so bile vzete izrazne in projektivne dimenzije otroških risb, ki lahko izkazujejo možnosti diagnostične in potencialne terapevtske dejavnosti v okviru rednega osnovnošolskega sistema. Projekt je poskušal preučiti tudi vpliv racionalno-kognitivnih načel poučevanja na ustvarjalnost in izražanje otrok.

Ključne besede: otroško likovno izražanje, diagnostika, izobraževanje, avtoportret, samoprojekcija 


\section{Introduction:}

\section{About the self-portrait and its use in the art class}

One's own character, one's own reflection and personal reflections are enduring human fascinations. The need to study and question oneself develops in parallel with the development of self-awareness. It is groundwork in the formation of the Ego. This need represents a logical quest for a person's own being, his/her integrity and self-actualisation as a primary goal in life. In this sense, the self-portrait represents a tangible manifestation of this quest, its beginning and end, a permanent record of variations of personal questions and answers. It is a record of the trajectory towards myself and a concretisation of I, summarised importance (Lacković-Grgin, 1994).

It is precisely due to the intrigue and importance of the self-portrait that we establish it as the framework of the present work and research. In the research, the self-portrait is presented primarily as a reflection of personality, a means of self-exploration and research in physical and psychological terms, a synergy of introspection and visual concretisation that often appears quite instinctively, without regard for time and age, and is common to all people.

Taking into account the various possibilities of self-portrait representation throughout the history of art (Jiang et al., 2017; Lucie-Smith \& Kelly, 1987), as well as the comprehension that an individual who is expressing him/ herself visually, consciously and unconsciously projects his/her personality into his/her work, and the fact that the human figure is the first universal visual identification factor that appears quite instinctively at the very beginning of visual expression development (Malchiodi, 1998) and successively reflects the development of the personality, the self-portrait finds a wide use outside art, especially as a projective diagnostic tool in psychiatry and paediatric psychiatry, psychology and therapeutic/rehabilitation activities (Alter-Muri, 2007).

In the field of art education, in many European countries and the USA, the self-portrait motif is recognised as an interesting starting point, both for various artistic research and for communicating and dealing with oneself. This is evidenced by the titles of some selected articles: The Significance of Self-Portraits: Making Connections through Monotype Prints in Letras y Arte (Armon et al., 2009); Self-Portraits with Expression (Daseler, 2001); Self-Portraits with a Twist (DeMarco, 2010); Self-History Project in Visual Arts Education (Coşkun, 2017); Face (in) the Mirror (Hoedekie, 2008).

In the case of teaching visual culture in Croatian primary schools, the self-portrait is not given special significance. The motive of self-portraits can only be found among visual stimuli, but always in context and depending on 
the specific teaching topics and units, with the aim of clarifying key concepts that are ultimately aimed at achieving the expected educational attainment. In this sense, the self-portrait corresponds to a visual task; it illustrates a visual problem. In the practical work of the students, the representation self-portrait motifs, just like any other visual or non-visual motif, depends on the individual teacher's preference. Although modern methods of teaching art should develop a creative approach and aim to explore the various forms of visual reality, they most often omit the necessity of primer identification, i.e., of subjective experience. Thus, the value of motifs in the visual arts, especially portraits, is reduced to mere visual form. This disregards their reflective, introspective and projective value, as well as the significance of self-exploration of the psychophysical personality structure, which is necessary for identification, self-awareness development and recognition of one's place in society (Nuñez, 2009). It is incorrect to think that the entire comprehension is realised only within the domain of reason; it necessarily includes an emotional (intuitive) aspect that is often indicated as essential for the acquisition of permanent knowledge, attitudes and values, as well as for the successful configuration of the whole personality.

Viewed as a reflection of the bio psychosocial personality structure, the self-portrait goes below the surface of the purely visual world. It opens the door to subjective and objective self-evaluation and may point to the essence and objective that are the aim of the development of the individual. It can have a diagnostic character and a reintegrating and revitalising effect, which is especially important in working with students with special educational needs, who are now commonly integrated into regular arts teaching programmes in Croatian schools. Unfortunately, in today's primary education system schedule, art classes are reduced to only 35 hours per year, during which all of the mandatory subjects must be implemented. This shortened timeframe does not provide the necessary conditions for the adequate development of this motif, nor does it enable the use of its multiple potentials (educational, identification, introspection and, potentially, therapeutic).

\section{Art project: The Self-portrait as a Means of Self-Exploration, Self-Projection and Identification}

The art project The Self-Portrait as a Means of Self-Exploration, Self-Projection and Identification emerged due to the specificity and importance of the motives of self-portraits in art and their common usage in diagnosis, therapy and rehabilitation. It is an interdisciplinary research project in which many 
insights from fine arts, psychology, educational science, art therapy expression and teaching arts permeate and complement the possibility of realisation within art classes in primary school. The need for this project arose from one of the new roles of art teachers. According to Pivac (2006), this is reflected in the teacher qualification for working with students with different abilities, difficulties, needs (cognitive, emotional, moral) and habits, as well as the multicultural differences that are encountered when teaching art in Croatian schools. It also includes the identification, prevention and treatment of traumatised children and youth through visual expression.

\section{The aim of the project:}

\section{The research problem and research questions}

The starting point of the project is considered to be within the expressive, projective dimensions of children's drawings and paintings, which suggest the possibility of diagnostic and potentially therapeutic effects. The construction of the project also aimed at examining the influence of the rational-cognitive principle in art teaching on children's creativity and expression.

The aim of the research project was to know whether the selected works of art used in the teaching of art culture could be not only a direct incentive for the art activity/creativity of the students, but also indirectly enable the students to express their personality in their artworks (not only in the artistic sense, but also in psychological terms). A further aim of the research project was to determine the extent to which the motive of the self-portrait allows students to express their personality.

In view of the goals set, the following research questions were constructed:

- Do selected works of art, especially through their emotional transfer, affect the expression of personality in the artworks of the student?

- Can a chosen self-portrait motif allow students to express their personality, and in what ways?

\section{Description of the project implementation}

The art project was realised in one of Split's primary schools, as a threehour block within regular teaching of art in fifth-grade classes. Twenty-eight students of around eleven years of age participated in the project. We selected this age group because students from the Arts Academy of the University of Split, with their professor as a mentor, performed art lessons in these classes on 
an ongoing basis and we therefore expected a high level of motivation among the children during the realisation of the project.

The research within this art project is based on a qualitative research paradigm that encompasses the method of observation, description and interpretation of a phenomenon, leading to new insights and the expansion and redefinition of our common understanding, as opposed to the generalisations and strict numerical classifications characteristic of quantitative research (Glaser \& Strauss, 1967; Willis, 1978). The research included three stages: data collection, content analysis and comparative analysis (Strauss \& Corbin, 1990).

Implementation of the project also entailed processing the curriculum scheduled by the primary school teaching curriculum content (Curriculum for Primary School, 2006). The teaching process for each of the teaching topics was performed during two school hours (90 minutes) and included the following stages: learning, creative games and activities, creation and evaluation.

During the first teaching topic, Surface - Figures on the Surface (key terms: figure, surface, two-dimensional, symmetry-asymmetry), the students were presented with reproductions of artworks: Black Square on a White Field, K. Malevich, 1915; People and Dog under the Sun, J. Miro, 1949 and Big Head, P. Picasso, 1962. In the practical realisation, the self-portrait had a simple title: This is Me. Considering that this title is quite instinctively reminiscent of the real image of one's own character, as a contrast it was stated that the realisation should be based upon the imagination. This shifted the focus of the creative act to the search, rather than the expected solution. This approach opens the possibility that the visual expression of a person becomes an instrument of communication, individualisation and integration. The students' visual artwork was made using the monotype graphic technique. Due to the specificity of this technique, the students expressed themselves directly and quickly, without having time for fear and superfluous questioning, which resulted in authentic expressive self-reflections of the given moment.

In the second teaching topic, Point and Line - The Course and Character of the Line, Structural Points and Lines (key terms: line course, line character, line construction, structure), the following reproductions were used: Portrait of Diego by A. Giacometti, 1940; detail of the artwork Holy Face by C. Mellan, 1649; and Head of an Angel by A. Sadeler, 1598. The motive of the second student artwork was a portrait of a class colleague in the coal technique. Coal provides a high level of accuracy, but also a distinct freedom and expressiveness, which can result in a series of random effects and a layered view. The portrait drawing took place alternately every 10 minutes. The main emphasis was directed not on showing the appearance of the person portrayed, but on expressing the 
feeling and emotions related to the person. This artistic product would present a combination of portrait and self-portrait, as it contains subjective reflection, the experience of another.

The third teaching topic was related to the Redefinition of the Surface (key terms: colour, redefining, re-composing). During this larger and more focused research, the students were presented with reproductions of artworks of A. Warhol, Marilyn Monroe, 1953 and P. Picasso Weeping Woman, 1937. Given that the visual element of colour is one of the key terms and essential components of practical work, the students were encouraged to become aware of the different possibilities of the experience of colour in the emotional, mental, physical, optical and symbolic sense. The motive of the third student art assignment was a self-portrait, but it involved reshaping the students' own physical reality. The students were given printed black and white photographs, their real self-portraits taken in the previous class, which they had to redefine by recomposing the shapes (breaking, cutting, pasting on the surface) and colour (warm and cold colours, pastels). The students' task was to change their selfportraits, not only in artistic terms (redefinition), but in terms of showing what they would like to change on their faces.

\section{Results}

Children's artwork is a permanent document that reflects numerous components in the process of its formation, both individual and social. It reflects not only the intellectual and emotional development of children, but also the impact of the environment, family and school. This was pointed out by Malchiodi (1998) when she explained the multidimensional aspects of children's drawings. Fifth-grade children (around 11 years) are at the age that corresponds to the phase of pseudorealism (Löwenfeld \& Brittain, 1987), which covers the period from 11 to 13 years. During this period, children tend to progress in optical-thematic form, but there is also a gradual stagnation in the creative abilities. Their artworks are based more on experience, knowledge, dexterity and skill, and less on expressiveness and originality. Pursuit of truer representation of the real is emphasised, and this is evident in dealing with movement, space and overall composition. Children aged around 11 years are in the period of early adolescence, so the characteristics of this developmental stage influence their artistic expression. Significant changes occur in terms of personality awareness, in the direction of strengthening oneself, and individuals question themselves with regard to interpersonal relationships, character and personal interests during this transitional period. This transitional period is therefore fluid and 
insufficiently constructive for artistic expression. Although there is substantial interest in the arts among individuals, certain negative reflexes also occur, such as a loss of attention towards and interest in artistic expression (Grgurić \& Jakubin, 1996; Malchiodi, 1998). At this developmental stage, children have not yet developed sufficient capacity for a full aesthetic experience, but the ability for the visual presentation of abstract concepts, appearances and feelings, with an emphasis to their specific communication, nonetheless begins to develop. If the works contain specific symbolic representations, they occur automatically and are often ambiguous, requiring careful reading.

Regarding the basic objective of the project, the primarily creative, expressive, reflective and projective dimensions of the children's drawings and paintings were analysed, taking into account the developmental level of the children and, inevitably, a certain degree of conditionality determined by the teaching subject. The children's drawings and paintings were categorised and analysed according to common features as well as the specific features observed in their artworks. By analysing and comparing the common and individual elements present in the children's works of art, we concluded that the selected works of art used in the study as a whole had an impact on the expression of personality in the artworks of the students. However, their influence is limited by the method of teaching, the time of experience, as well as by the personality of the individual child and his/her responsiveness to the individual work of art. Moreover, at this age, the expected level of reception of an artwork is spontaneous and critical. It is precisely these levels of reception and responsiveness to the selected works of art that are observed in the detailed analysis and the comparison of the student works of art presented below. The common elements present in the drawings and images are generally expected, while the specific elements are unexpected and may indicate emotional and intellectual deviations from the expected developmental phase of the student. By analysing the individual artworks of the students created in this project, we concluded that the selected self-portrait motif as an incentive for artistic expression enabled students to express their personality in different ways, and to a greater or lesser extent. All of the ways in which the motive of the self-portrait encouraged the students to express certain aspects of their personality are shown below, highlighting the influence of gender, age, motivation and the artwork they experienced as key variables. Based on the observation method (which included analysis and comparison) and description and interpretation of the students' artwork, we conclude that the results of the research carried out during this art project gave positive answers to both of the research questions. 


\section{Analysis of the students' artworks with regard to common features}

We can observe typical negative impacts of this developmental phase in several of the artworks created during the implementation of this project. This came to the fore especially during the methodical elaboration of the theme Point and Line - The Course and Character of the Line, Structural Points and Lines. It is conditioned by the negative reaction to the selected reproduction of the A. Giacometti artwork, which has an expressive, cathartic nature, or by the identification with the works of C. Mellan and A. Sadeler, which have a very technical nature. With the exception of a few highly subjective-expressive works, most of the students resorted to the formal implementation of the task. These student artworks do not show great expressive quality or a special creative approach in developing visual problems; most of them tend towards a stereotypical impression derived from the visual disparity between desires and abilities. These works require a very different reading, which is particularly related to the work of girls.

\section{Figure 1}

Female student A. V. drawing, portrait of A. B., $5^{\text {th }}$ grade

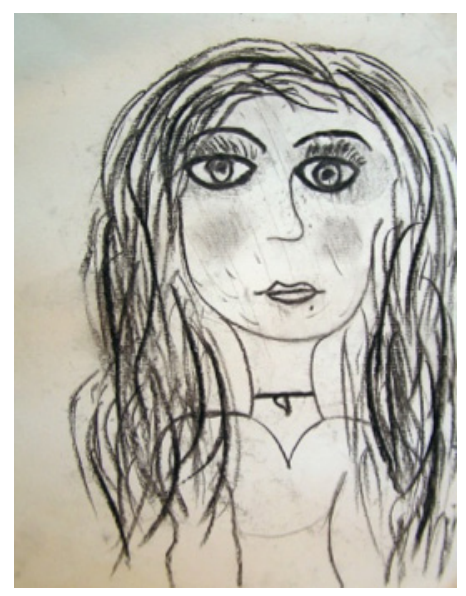

\section{Figure 2}

Female student A. B. drawing, portrait of A. V., $5^{\text {th }}$ grade

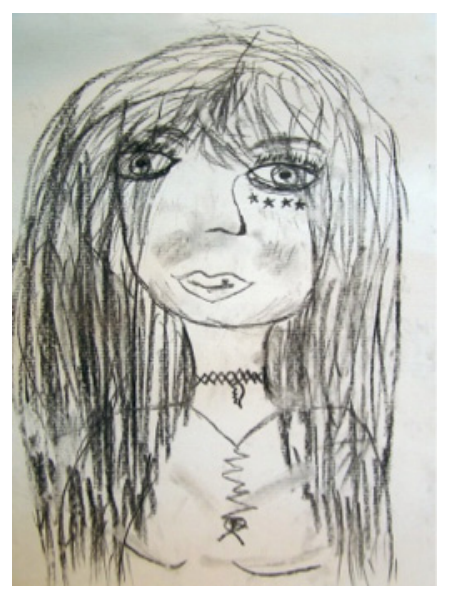




\section{Figure 3}

Female student M. M. drawing, portrait of S. S., $5^{\text {th }}$ grade

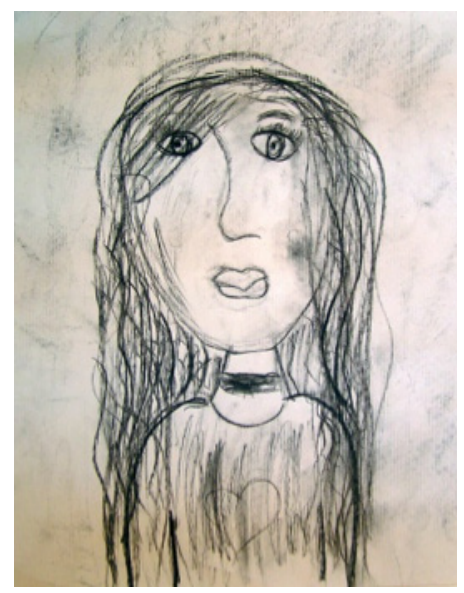

Figure 4

Female student S. S. drawing, portrait of M. M., $5^{\text {th }}$ grade

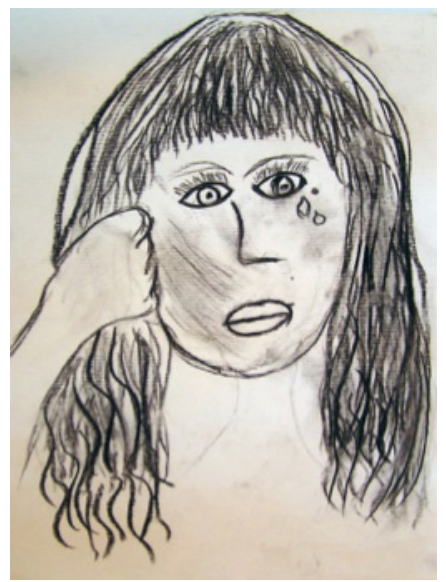

The portraits of the school bench colleagues shown (Figures 1, 2, 3 and 4) represent works by four girls who were sitting on two benches, one in front of the other. In their artwork, one can observe:

- $\quad$ an extraordinary similarity derived from mutual influence;

- a tendency towards idealisation and quaintness, implemented by drawing a template (template drawing indicates a desire and approach by which the child identifies with the environment in easiest way);

- a careful enumeration and rendering of women's attributes, which points to the definition of gender and is a reflection of the expected mental and physical development of adolescent girls;

- $\quad$ emotions are not explicitly expressed, but can be inferred from the mutual influence, a sort of principle of appeasement and community (this may indicate strength of character, submission or supremacy in dependent relationships, an ability to adapt to certain deviations);

- $\quad$ added symbolic repertoire in different constellations (if it exists, it could be read as an individual personality characteristic).

We find a similar mode of artistic expression in many other examples, predominantly female work. Such works of art remain sketchy, reflecting a blank artistic form and lacking quality or projective expressive values.

We encounter the same problem in the works of the male population. This mainly arises from the identification and fascination with the technical aspect of the works of C. Mellan and A. Sadeler. However, such works are rare. 
Generally, with regard to the works by the male population we can observe that:

- they rarely show mutual influences and similarities (which may indicate a greater degree of independence in searching for own expression, arising from a desire to prove themselves);

- $\quad$ they are more experimental (they provide a wide variety of experience and expression, and various subjective-expressive variations in order to prove themselves);

- they do not explicitly express emotions (because a such mode of expression is seen as a weakness);

- most of the works of students made during this lesson are self-portraits according to their psychological content, because they take the form of portraits (the face of the colleague in the school bench) solely as a means of indirect representation, the promotion of oneself (the inscriptions on the back of the drawings support this, with some students writing: from...to... or work made by...).

\section{Figure 5}

Male student J. C. drawing, portrait of P. B., $5^{\text {th }}$ grade

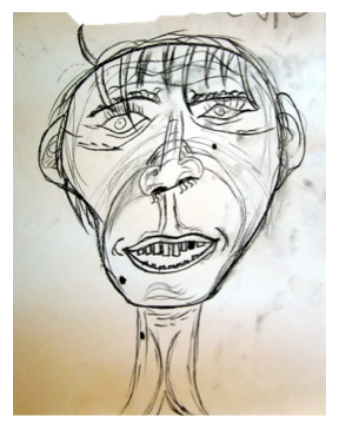

Figure 6

Male student P. B.

drawing, portrait of J.

C., $5^{\text {th }}$ grade

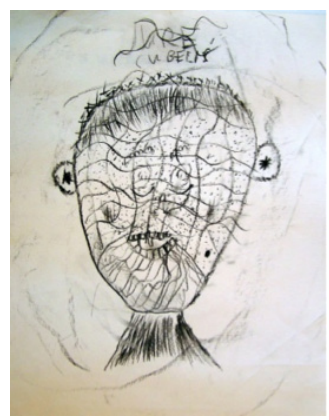

\section{Figure 7}

Male student M. M.

drawing, portrait of A.

D., $5^{\text {th }}$ grade

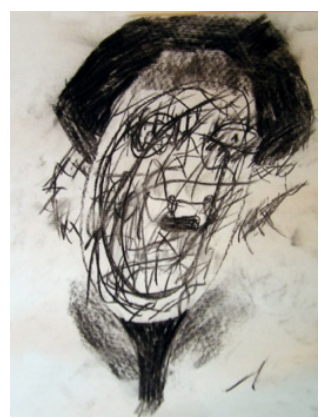

Some students were arranged to sit together, despite their opposition. The tensions arising from this relationship can, to some extent, be read from their works. In the case of the artwork in Figure 5, these tensions are manifested through the caricature view. In the work in Figure 6, they speak through the structure of the face, which cancels and covers all of the individual facial features, including the name of the person portrayed. Although the artwork of A. M. (Figure 7) has a highly expressive nature, there are very few references to the actual appearance of the person portrayed. In this case, the portrait serves merely as a background for expressing their tensions. 
When setting the goals to be realised in the first motif of the self-portrait lesson Surface - The Characters on the Surface, the students were not asked to represent the emotions and experiences that they were able to express through artistic expression; they had great freedom of expression (limited only by selecting the number of colours that they were able to use: two colours of their choice - one warm and one cold - as well as black). There was a tendency to dismiss the real physical appearance in favour of the imagination. The self-portraits created during this lesson are imbued with the specific child's symbolism, subject to their own rules. Individual symbolism derives from the ways in which children identify with the world and identify themselves, so it is a logical reflection of psychosexual orientation. Moreover, it is noticeable that the content and artistic treatment of many of the works go beyond the simple male-female conception, and therefore resist similar rigid categorisations.

In general, all of the works present unique reflections of different personality and character, in which:

- $\quad$ interdependent negative impacts do not come to the fore significantly;

- $\quad$ works by boys and girls mostly have a very positive effect;

- $\quad$ as expected, girls were more prone to female gentle symbols, themes and handwriting (the most common identifying attributes are hair, eyes, blush and to a lesser extent the mouth (Fig. 10); within the symbolic presentation they are more prone of gentle forms that are suggestive, e.g., the shape of the sun, flowers, etc., and often use warmer colours and brighter colour combinations, although this may not necessarily be the case);

- boys have a slightly more aggressive approach and artistic repertoire (identification attributes are manifested, for example, in painting the beard, emphasising the teeth and mouth, with some aggressive content, such as a black eye (Figure 8), or various beasts, such as Cyclops (Figure 9).

\section{Figure 8}

Monotype, self-portrait Black Eye of male student J. C., $5^{\text {th }}$ grade

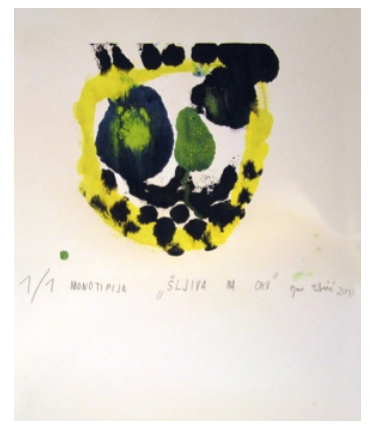

Figure 9

Monotype, self-portrait Monster of male student T. M., $5^{\text {th }}$ grade

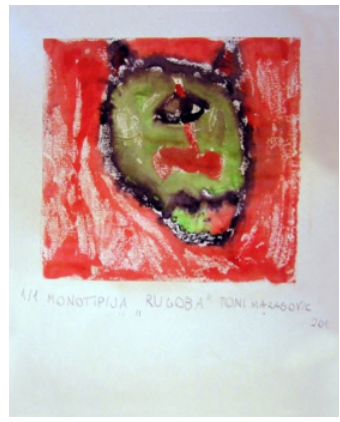

Figure 10

Monotype, self-portrait

Ugly Doll of female student D. F., $5^{\text {th }}$ grade

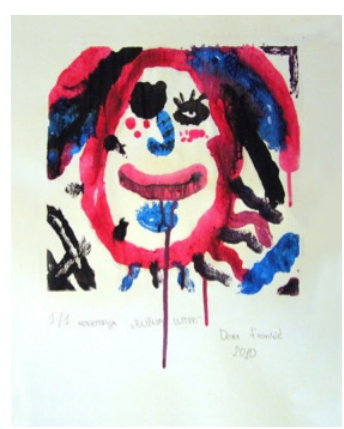


Of course, all of the aforementioned results derive from a variety of environmental influences and traditions, as well as different educational and social norms, and reflect the child's receptivity of these factors and ways of dealing with them. Moreover, all of what has been described thus far points to the necessity of a deeper level of reading different constellations of individual symbolic and universal characteristics of children's drawings. In this regard, we should also bear in mind that an adequate analysis of individual child works cannot be based on just one drawing, and necessarily requires a comparison of all of the works made in the project. The presented works (Figures 8, 9 and 10) are some of the examples in which specific differentiated attributes, symbols and themes can be noted as reflections of the psychosexual orientation of the children. Some of the works survived with the initial title This is $\mathrm{Me}$, but some of the students gave titles to their works themselves, e.g., Black Eye, Monster, Toothy (in the case of boys), or Ugly Doll, Monster, Colourful Thong (in the case of girls). In the case of both boys and girls, these titles (with the exception of the last title) imply negative content that may suggest resistance, defiance or exhibitionism, but may also indicate genuine negative connotations.

The visual artworks shown below (Figures 11, 12 and 13) belong to a group that is not subject to differentiation by gender characteristics. These are works of a universal character, containing archetypal shapes and formations (such as a square, a circle, a mandala shape, the symbol of trees, houses, etc.) as stated by Jung (1968), but they are characterised by distinct and subjective symbolism, which requires a special approach in analysing the visual elements of form and content. Such acts are present in equal measure in the works of boys and girls, and are particularly interesting and open to multi-layered reading.

\section{Figure 11}

Monotype, stencil, unknown student, $5^{\text {th }}$ grade

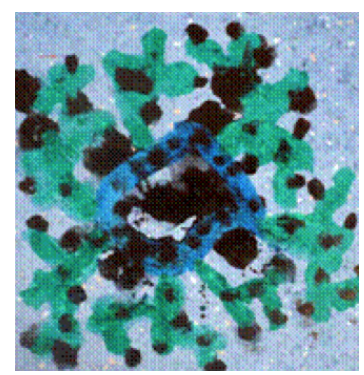

\section{Figure 12}

Monotype, self-portrait This is Me of female student M. D., $5^{\text {th }}$ grade

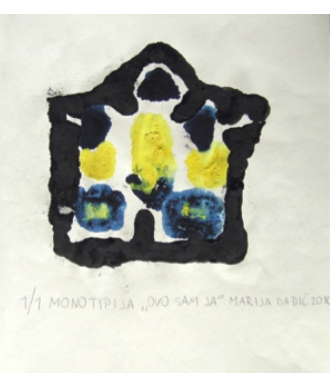

\section{Figure 13}

Monotype, a self-portrait Monster of female student A. P., $5^{\text {th }}$ grade

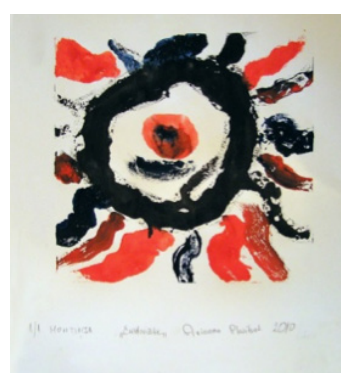


In the last segment of the teaching project, Redefinition of the Surface, the students used their own photographs (printed black and white portraits taken at the previous class) in the visual realisation of the task, which they use to achieve a new visual reality in the process of re-composition of the colour. The students were encouraged to think and express what they wanted to change about themselves. The use of colour was relatively limited to the relations of warm and cold colours, with regard to which their symbolic significance and use was primarily discussed. Although the majority of the artworks created during this lesson again represent a unique example of the children's imagination and a wide variety of subjective considerations, unlike those previously described, these works are less constructive: there is a certain degree of disintegration and occasionally we find traces of the template.

Perceiving the work process, it can be observed that in the self-portraits: - the task is not of particular value to boys (which indicates the lower degree of importance they attach to physical appearance; personal photos are treated as part of the technical material);

- boys are more in favour of experimentation and exploration of technical possibilities (without fear of approaching the decomposition of their own portrait; however, the lack of identification with their own character can be negatively reflected in the creative process and result in works that do not contain actual expressive auto-projection);

- $\quad$ girls establish the emotional connection with the photo at the very beginning (they want to preserve it and reluctantly approach the process of decomposing);

- most girls retain greater integrity of their compositions with minimal colour changes and upgrades, or accentuate the elements that they like the most in the portrait, although the task was exactly the opposite;

- $\quad$ some examples of girl self-portraits have a tendency to present the final explicit expressions of feelings (usually elements of the template); the feelings presented in this way do not necessarily reflect the real situation: they may only represent a blank form resulting from the aspiration for the consistent execution of visual tasks).

It should be noted that this work process inevitably requires the degree of self-criticism, observing and questioning one's own conflict zones, for which students may not have been ready or did not want to communicate openly. Furthermore, the ability of conscious symbolic transcription of the content, which, in this case, could provide students a degree of security and freedom, is just beginning to develop at this developmental stage. 
Figure 14

Re-composition, self-portrait of female student Z. K., $5^{\text {th }}$ grade

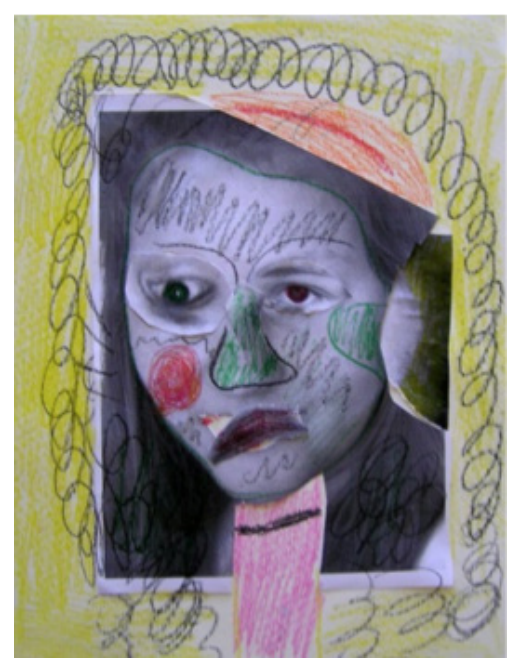

Figure 16

Re-composition, self-portrait of male student J. C., $5^{\text {th }}$ grade

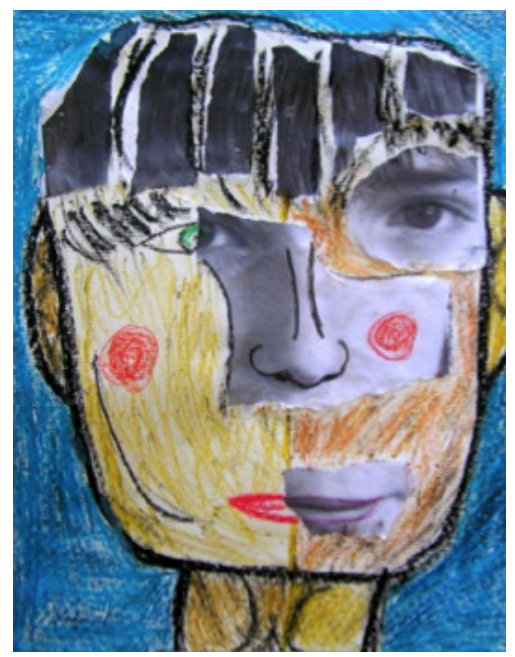

\section{Figure 15}

Re-composition, self-portrait of female student D. D., $5^{\text {th }}$ grade

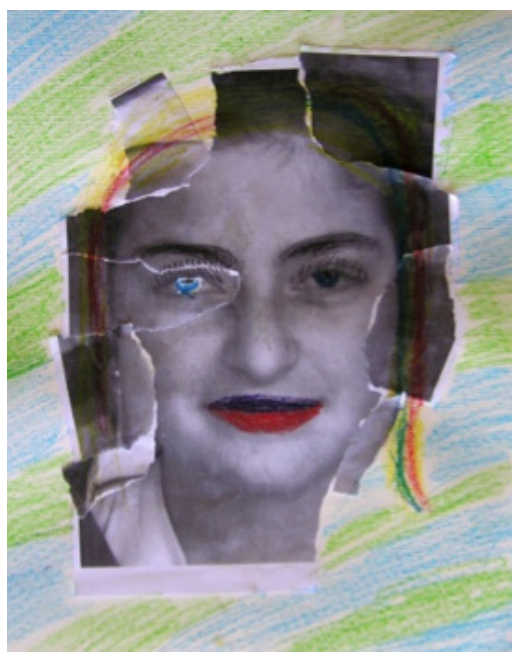

Figure 17

Re-composition, self-portrait of male student P. B., $5^{\text {th }}$ grade

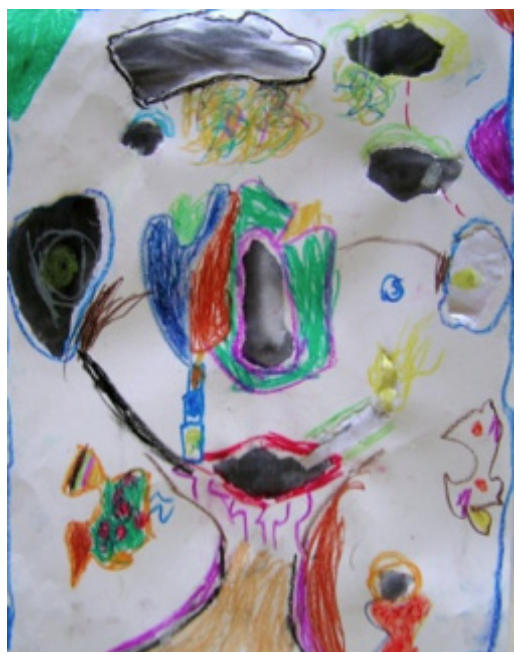

\section{Analysis of the students' artworks regarding specific features}

In the current review of children's artworks created during this project, we investigated the projective, cathartic and potentially diagnostic and 
therapeutic possibilities of self-portraits in education. Attention was given to certain specific impacts arising from the cohesion of the teaching process, the students' level of development, and social interaction. The students' work was analysed in the context of the general and the collective, and thus we defined the regularities and accented the differences that arise in the clash of individual and general, subjective and objective, conscious and unconscious, and that are present within the school class. In this way, we have tried to create a starting point for further analysis of the students' works in terms of individual diagnostics.

In achieving this goal, and for the purposes of the present paper, we will present the individual creative products of one student that can be sorted and categorised according to the principles of subjective expression. The analysis will cover the entire set of works made by the student during the project. We will consider motivation, the course of the creative process, the use of technical materials, visual elements, compositions, present content, and consistency and discontinuity in utterance, as well as detecting whether some discrepancies are present. When analysing the works, we will also take into account the personality of the student, the way he acts and presents himself within the class collective.

Of course, this project is of a very experimental nature in order to study the projective and potentially prophylactic possibilities of artistic expression, rather than making an individual diagnoses. Diagnosis of the cognitive and affective aspects of a personality that could indicate a negative deviation from the standard requires the work of an interdisciplinary team of experts, which cannot be achieved during the teaching process (De Zan, 1994; Pivac, 2006).

\section{Student P. B., $5^{\text {th }}$ grade}

In terms of social adaptation, student P. B. seems isolated to a certain extent. The lack of social engagement is evident. However, this student does not aim to change the existing situation, but lets it remain the way it is. He rarely participates independently in the educational dialogue, he is hard to motivate, and he is reluctant to execute his work, so it mostly remains unfinished. One possible source of all of these problems is a fundamental lack of concentration and focus. Consequently, his works are rarely appropriate to the specific teaching assignment and do not reflect a systematic approach, creating the impression of confusion and disintegration. The positive features of his works are derived from instinctive impulses, with an accent on unconscious processes, giving them a very clear expressive-projective value. The student does not show a tendency towards compensation for negative feelings through his artistic 
expression. In addition to the standard stereotypical patterns of behaviour characteristic of his age, he does not express the need to define his psychosexual orientation. His works therefore have no role as a means of identification, at least not on a conscious level, and the effort that students might make in pursuit self-actualisation through the creative process is absent.

During the first teaching unit of the project, which includes artistic work on the motive of self-portraits, the student made two matrixes (Figures 19 and 20), both of which are poorly made in a technical sense, so their printing was unsuccessful. The first matrix (Figure 19), which is a collection of failed attempts, is partially preserved. The stains that it contains are the traces of the constant rewrites; they suggest insecurity and an inability to make a decision. The first stage of realisation of the matrix contained a snowman in the lower left corner, along with the sun and birds (pattern), which can still be seen in the upper part of the matrix. The snowman was very small in relation to the surface and was outlined in a timid, meandering thin line in a contour only, without filling the surface with paint. In the far lower left corner, the remains of his leg can still be seen. This placement of the main identifying character in the corner leaves a great deal of empty, negative space on the surface. In his work, the student selects colours arbitrarily. In this case, there is a combination of red, brown and black, whose interdependent operations create a negative impression (the black birds in the upper part of the matrix). In the second stage of the realisation of the matrix, after deleting the previous drawing, we see the beginning of an idea that will occur on the second matrix. It is a composition made up of a series of interconnected black circles (Figure 20) with a set of points scattered in the background. According to Rudolf Arnheim (1982), the circle is the most basic visual circuit and the first organised form that occurs in children's artistic expression development. It can symbolise the experience or knowledge of oneself as a separate entity. In this paper, the circle appears in its original symbolism, but the manner in which the student arranges the circles on the surface suggests a different reading. By creating a conglomerate of circles, the student denies the positive aspects of this symbol, instead suggesting diversification and an inability to focus. The scattered points in the background present the repeated circle shape; therefore, the composition may suggest the repetition of a certain state, or its durability without the possibility of change. In this context, the circle may suggest durability, containment and isolation. The colour is almost completely abolished, so we only see traces of red. 
Figure 18

Photo of student P. B., $5^{\text {th }}$ grade

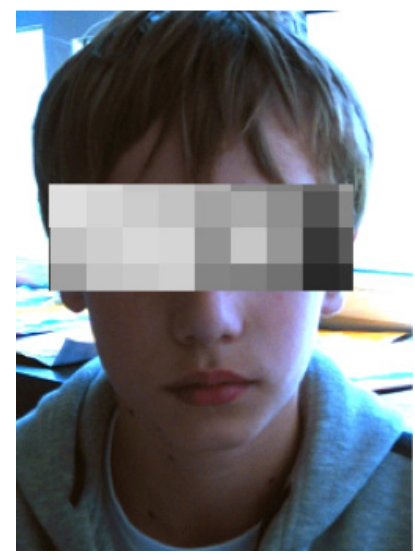

Figure 19

Monotype, stencil of student P. B.

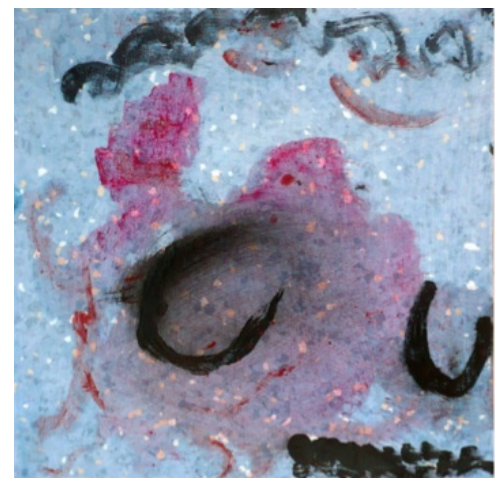

Figure 21

Male student P. B. drawing, portrait of J. C. (colleague on bench)

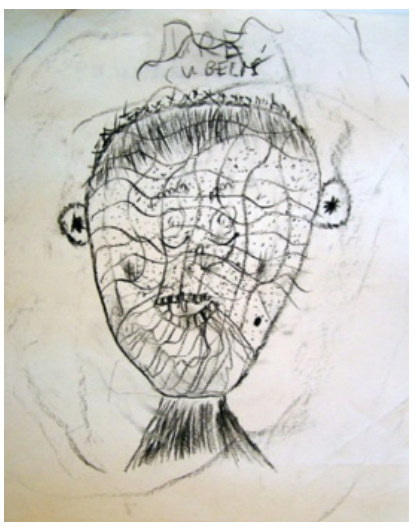

\section{Figure 20}

Monotype, stencil of student P. B.

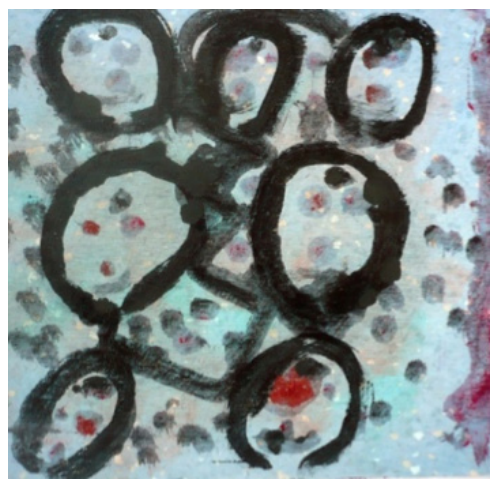

Figure 22

Re-composition, self-portrait of student P. B.

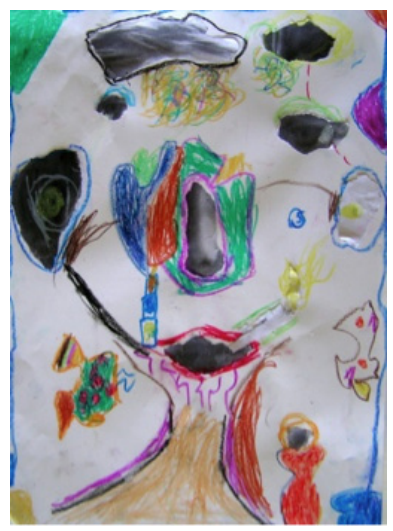


If we analyse all of the factors observed in terms of the flow of the creative process (insufficient level of motivation, lack of concentration, indecisiveness, inability to perform the task, how to use technical materials) and the content (described visual elements, their location, negative space, symbolic content), these works have a negative diagnostic sign and indicate the possible need for therapeutic effect.

The remaining works (Figures 21 and 22) of this student do not indicate negative connotations, but they do contain some of the aforementioned features, such as the impossibility of identification, the inability to concretise, incompleteness, etc. When making portraits of a colleague on a school bench (Figure 21), the student was moved to sit with the student, with whom he does not normally sit (imposed situation). The student accepted the situation without excessive emotions. The work task sought to create a portrait with structural lines in order to express their own impressions and feelings related to the portrayed person. In technical terms, the student completed his task. We can notice that the entire face is made of variations in different structures, different expressive potential. In psychological terms, we note that although the face has all of the elements (eyebrows, eyes, circles under the eyes, a nose, a mouth, emphasised teeth, flush, a mole, etc.), all carefully drawn, the student denies those elements by making a network of wavy lines across the face like a wire membrane. In this case, we also find a characteristic dotted pattern applied to the face, which may suggest a dispersal of thought, as well as wavy lines that hover around the head covering the portrayed person and the name inscribed in the upper part of the paper. Regarding the character of the line, it is primarily wavy and gentle, and does not reflect determination but rather fluidity, movement, multi-faceted orientation.

The last work of the student (Figure 22) is particularly interesting for its relatively unusual method of composition: the use of different colours and free forms that are difficult to define and to attach any meaning to. This work is rich in subjective symbolism that is not subject to standard terms of reading and definitely requires a verbal explanation of the student. Despite the fact that the work makes a positive impression with its coloration, we notice a lot of empty space, which the student seeks to fill by drawing and accumulating unusual shapes and objects. Furthermore, we notice that the face has no contour lines; it actually opens up from the neck up. Visible are the wavy lines that run from the mouth across the chin, which might represent a beard, an attribute of masculinity, as well as the cigarette in his mouth. The neck is this time mottled in colour, as in the case of the previous portrait. The line that runs from the upper-right corner - connecting the eye, the right ear, above the nose, the left ear and down 
the cheek to the mouth - is particularly interesting and unusual. As in the previous works, the overall composition gives the impression of disintegration and confusion. Considering that the assignment in this task was for the students to show what they wanted to change about themselves, this unusual work certainly demands further analysis and reading.

\section{Conclusion}

Due to the fact that our own character and its reflection represent one of the enduring human fascinations, the motive of self-portraits was established as the framework of this project. Self-portrait is, at the same time, presented as a reflection of personality, and is potentially a means of self-exploration and research in the physical and psychological sense. The project results indicate the possibility of an appropriate application of the self-portrait, not just as an artistic motif, but also as a projective diagnostic and potentially therapeutic agent. Analysis of the students' artworks showed that they generally correspond to the expected developmental stage of artistic expression of children of around 11 years; however, it also indicated individual differences that would require orientation towards further diagnostic and therapeutic actions.

The extremely small unit of the subject Visual Culture in Croatian primary schools ( 35 hours per year) and the extremely rational cognitive-oriented principle of teaching, conditioned by the propositions of the Curriculum for Primary School (2006), unfortunately does not provide adequate conditions for this kind of action. Although, through the realisation of this project, the motive of the self-portrait successfully exhausted the projective, diagnostic dimensions of children's drawings and paintings, a further therapeutic procedure would inevitably demand the establishment of separate art workshops with the aim of providing adequate attention to children with such needs. Through them, sensitised art teachers (individually or in teams with other professionals) would really be able to carry out their motivational (encouraging creativity and experience), supportive (emotional and moral), mediation (a mediator between the sign and meaning) and partly therapeutic role, according to Pivac (2006).

For the purposes of the prophylactic and therapeutic use of artistic expression within the education system, it would be necessary to upgrade the dominant rational-cognitive process of learning and teaching art with the emotional dimension of experience. As Pivac (2009) explained, this change would enable better understanding not only of visual art phenomena, but also of the ability to achieve a fuller aesthetic experience and an understanding of the creative process, and to influence the development of empathy and visual and 
communication skills, as well as identification, projection and self-realisation, thus rebuilding the personality through art. This is precisely what the new curriculum for teaching the subject Visual Culture in primary schools in Croatia (2019) allows. Such efforts, worldwide, are being promoted by the Australian project ELVA (Enhancing Emotional Literacy through Visual Arts), an innovative approach developed by the Dax Centre, which incorporates visual arts and mental health for school students (Nikon, 2016).

Finally, we would like to stress that the conclusions we have reached based on the results of the research undertaken within this art project are nevertheless limited by the small number of students who participated. Therefore, future similar research will confirm or reject our conclusions.

\section{References}

Alter-Muri, S. (2007). Beyond the face: Art therapy and self-portraiture. The Arts in Psychotherapy, 34(4), 331-339.

Armon, J., Uhrmacher, P. B., \& Ortega, T. (2009). The Significance of self-portraits: Making connections through monotype prints in Letras y Arte. Art Education; Reston, 62(6), 12-18. Arnheim, R. (1982). Art and visual perception: A psychology of the creative eye. University of California Press.

Coşkun, N. (2017). Self-history project in visual arts education. International Journal of Education Through Art, 13(3), 349-367. https://doi.org/10.1386/eta.13·3·349_1

Daseler, J. C. (2001). Self-portraits with expression. Arts and Activities; Skokie, 129(2), 46-47.

De Marco, F. (2010). Self-portraits with a twist. Arts and Activities; Skokie, 147(3), 38-39.

De Zan, D. (1994). Slika i crtež u psihoterapiji djece [Image and drawing in children's psychotherapy]. Hrvatski pedagoško-književni zbor.

Glaser, B., \& Strauss, A. (1967). The discovery of grounded theory. Aldine Publishing.

Grgurić, N., \& Jakubin, M. (1996). Vizualno-likovni odgoj i obrazovanje [Visual art education]. Educa. Hoedekie, N. (2008). Face (in) the mirror. In T. Eça, \& R. Mason (Eds.), International dialogues about visual culture, education and art (pp. 111-118). Intellect.

Jiang, H., Liang, X., \& Chen, G. (2017). Research on self-portrait artistic creation. Advances in Social Science, Education and Humanities Research, 123, 9-13.

Jung, C. G. (1968). Man and his symbols. Dell Publishing.

Kurikulum nastavnog predmeta Likovna kultura za osnovne škole i Likovna umjetnost za gimnazije [Curriculum for teaching subject Visual Culture for primary schools and Visual Art for upper secondary schools]. (2019). Ministarstvo znanosti i obrazovanja, Republika Hrvatska.

Lacković-Grgin, K. (1994). Samopoimanje mladih [The self-concept of youths]. Naklada Slap. Löwenfeld, V., \& Brittain, W. L. (1987). Creative and mental growth (8th ed.). Macmillan Publishing. Lucie-Smith, E., \& Kelly, S. (1987). The self portrait: A modern view. Sarema Press. 
Malchiodi, C. A. (1998). Understanding children's drawings. The Guilford Press.

Nastavni plan i program za osnovnu školu [Curriculum for primary school]. (2006). Ministarstvo znanosti, obrazovanja i športa, Republika Hrvatska.

Nikon, M. (2016). Knowing me knowing you: Enhancing emotional literacy through visual arts. International Journal of Education through Art, 12(2), 181-193. https://doi.org/10.1386/eta.12.2.181_1 Nuñez, C. (2009). The self portrait, a powerful tool for self-therapy. European Journal of Psychotherapy and Counselling, 11(1), 51-61. https://doi.org/:10.1080/13642530902723157 Pivac, D. (2006). Uloga učitelja likovne kulture u prepoznavanju, prevenciji i terapiji traumatizirane djece [The role of art teachers in recognition, prevention and therapy of traumatised children]. Napredak, $147(2), 222-227$.

Pivac, D. (2009). Likovno umjetničko djelo kao poticaj likovnog izražavanja učeničkih emocija [The visual work of art as a stimulus for students' visual expression of emotions]. In H. Ivon (Ed.), Djeca i mladež u svijetu umjetnosti (pp. 93-106). Centar za interdisciplinarne studije - Studia Mediterrane, Filozofski fakultet Sveučilišta u Splitu and Hrvatski pedagoško - književni zbor, Ogranak Split. Strauss, A., \& Corbin, J. M. (1990). Basics of qualitative research: Grounded theory procedures and techniques. Sage Publications.

Willis, G. (1978). Qualitative evaluation as the aesthetic, personal, and political dimensions of curriculum criticism. In G. Willis (Ed.), Qualitative Evaluation: Concepts and Cases in Curriculum Criticism (pp. 2-18). McCutchan Publishing.

\section{Biographical note}

Dunja Pivac, $\mathrm{PhD}$, is an assistant professor in the field of teaching visual arts and research in visual art education in the Arts Academy at the University of Split in Croatia. Her research interests mainly include teaching and learning in visual arts, action research, art based projects with students, implementation of art therapy approaches in different educational context and professional development of art teachers.

Maja Zemunik, MD, is an assistant professor in the field of graphic art and research in graphic art in the Arts Academy at the University of Split in Croatia. Her artistic interests include research in different graphic fields and techniques, art based projects with students and art teacher education. 